\title{
High prevalence of Entamoeba moshkovskii infection in HIV seropositive patients of Barak Valley, Assam, India
}

\author{
Joyobrato Nath ${ }^{1,2}$, Sankar K Ghosh², Prithwiraj Bhattacharjee ${ }^{3}$, Jaishree Paul ${ }^{4}$, Baby Singha ${ }^{1 *}$ \\ From 2nd International Science Symposium on HIV and Infectious Diseases (HIV SCIENCE 2014) \\ Chennai, India. 30 January - 1 February 2014
}

\section{Background}

It is now well established that Entamoeba moshkovskii and Entamoeba dispar are two distinct non-pathogenic species, microscopically indistinguishable from pathogenic Entamoeba histolytica. Being endemic, there are no data on the prevalence of these commensal infections from the North Eastern part of India.

\section{Methods}

A total of 274 stool samples collected in this cross sectional study from HIV seropositive patients attending the ART centre of SMCH, Assam, India were screened for cyst and/ trophozoite stage of Entamoeba using iodine staining technique and then subjected to $S S U$ rRNA gene based multiplex PCR assay.

\section{Results}

Out of 274 stool samples, multiplex PCR assay of 61 microscopy positive samples showing cyst and/ trophozoite stage of Entamoeba, revealed a higher prevalence of E. moshkovskii $(12.8 \% ; 95 \% \mathrm{CI}=9.30,17.28)$ and lower prevalence of $E$. dispar $(6.2 \% ; 95 \% \mathrm{CI}=3.85,9.77)$ compared to E. histolytica $(8.1 \% ; 95 \% \mathrm{CI}=5.31,11.91 ; p<0.05)$. Of the 61 samples that were microscopically positive, 5 were E. histolytica, 8 were E. dispar, 25 were E. moshkovskii, 17 were mixed infections with $E$. histolytica and 6 were PCR negative which may be non-histolytica/dispar/moshkovskii infection. Thus, only $36 \%$ of the 61 microscopy positive stool samples were actually $E$. histolytica, implying that remaining $64 \%$ of so called infections were over represented and would have been treated unnecessarily.

\footnotetext{
* Correspondence: babysingha@gmail.com

${ }^{1}$ Department of Zoology, Gurucharan College, Silchar, Assam, India
} Full list of author information is available at the end of the article

\section{Conclusion}

This is the first report of E. moshkovskii infection from this region of India and its high prevalence signifies an urgent need of amoebiasis diagnosis using advanced molecular tools to avoid overrepresentation and unnecessary chemotherapy.

\section{Authors' details \\ ${ }^{1}$ Department of Zoology, Gurucharan College, Silchar, Assam, India. ${ }^{2}$ Department of Biotechnology, Assam University, Silchar, Assam, India. ${ }^{3}$ Department of Medicine, Silchar Medical College and Hospital, Silchar, Assam, India. ${ }^{4}$ School of Life Sciences, Jawaharlal Nehru University, New Delhi, India.}

Published: 27 May 2014

\section{doi:10.1186/1471-2334-14-S3-P1}

Cite this article as: Nath et al:: High prevalence of Entamoeba moshkovskii infection in HIV seropositive patients of Barak Valley, Assam, India. BMC Infectious Diseases 2014 14(Suppl 3):P1.

Submit your next manuscript to BioMed Central and take full advantage of:

- Convenient online submission

- Thorough peer review

- No space constraints or color figure charges

- Immediate publication on acceptance

- Inclusion in PubMed, CAS, Scopus and Google Scholar

- Research which is freely available for redistribution

Submit your manuscript at www.biomedcentral.com/submit
() Biomed Central 